\title{
Considering YouTube's value as a historical source, with reference to the 2015-2017 drought in the Vaal Triangle
}

\author{
Annadine Smit ${ }^{*}$
}

\begin{abstract}
The 20th to 21st century has seen dramatic changes in the amount of available information from which researchers can obtain insights into people's past experiences. Traditionally, historical insights were derived mainly from archival and physical sources. Oral interviews also offered new perspectives as well as challenges for the interpretation of histories. Increasingly, social media provide researchers not only audio and/or visual material, but also unique combinations of these two mediums. The wave of technological innovation affords the ordinary person the opportunity to record, store and share his or her life experiences. The extent to which this is occurring is also testimony of the information age. For historians this not only provides a rich array of sources, but also requires them to take new responsibility regarding internal and external source criticism, along with a keen sense of knowledge of the available technologies. As one such platform YouTube is being used increasingly to capture and share life experiences. One such example the 2015-2017 drought in the Vaal Triangle. For contemporary historians, social media provides unique opportunities to investigate, with the appropriate analytical mind-set, such 21st century historical phenomena.
\end{abstract}

Key words: Social media; YouTube; Regional History, methodology; sources, Vaal Triangle.

\section{Opsomming}

Die 20ste tot 21ste eeu het dramatiese veranderinge teweeggebring in die hoeveelheid beskikbare inligtingsbronne waaruit navorsers insigte kan verkry oor sekere historiese menslike ervarings. Tradisioneel is argiewe en/of fisiese historiese bronne ondersoek vir historiese insigte. Mondelinge onderhoude het ook nuwe perspektiewe, asook uitdagings, vir die interpretasie van geskiedenis ingehou. Sosiale media bied aan navorsers nie net al hoe meer oudio- en/of visuele materiaal nie, maar ook unieke kombinasies van hierdie twee mediums. Die uitbreiding van tegnologiese innovasie bied die alledaagse persoon die geleentheid om sy of haar lewenservarings op te teken, te stoor en te deel. Die skaal waarop dit plaasvind is ook 'n weerspieëling van die inligtingsera. Vir historici bied dit nie net 'n magdom bronne nie, maar vereis ook 'n nuwe verantwoordelikheid in terme van interne en eksterne

* Annadine Smit is based in Vereeniging and is enrolled for a Master's degree in History under Prof Elize S. van Eeden and Dr Claudia Gouws at the North-West University. Her current research pertains to the historical experience of drought and the use of social media as source for historical inquiry. Her email address is: annadinesmit@gmail.com How to cite this article: A. Smit, "Considering YouTube's value as a historical source, with reference to the 2015-2017 drought in the Vaal Triangle", Historia, 64, 1, May 2019, pp 140-165. 
bronnekritiek met bygaande kennisname van die beskikbare tegnologieë in gebruik. YouTube, as sosiale media bron, is een van die platforms wat toenemend gebruik word om lewenservarings oudiovisueel vas te vang en te deel. Een so 'n ervaring is die belewenis van die 2015-2017 droogte in die Vaaldriehoek. Vir kontemporêre historici bied dit unieke geleenthede om historiese momente, wat deur 21ste-eeuse samelewings vasgevang word, steeds krities te ondersoek.

Sleutelwoorde: Sosiale media; YouTube; Streeksgeskiedenis; metodologie; bronne; Vaaldriehoek.

\section{Introduction}

Most historians agree that history does not repeat itself. ${ }^{1}$ However, different findings may come to the fore as new technologies present fresh perspectives on past events. The rapid change in technology provides historians with the opportunity to explore historical events from a broader field of available data and not necessarily from a topdown or bottom-up approach. It is noted that from the post-modernist perspective, ${ }^{2}$ researchers ought to look into all possible avenues for evidence as new kinds of histories (especially histories with a bottom-up view ${ }^{3}$ ) become available. ${ }^{4}$ It is partly the purpose of this paper to see if social media, as one such possible source, has been used by historians to this extent. This is accompanied by a critique on its value for the discipline of History. Social media can provide the historian with the opportunity to investigate the oral history contributions of ordinary people to the regional (and thus public) history of, for example, drought, when victims share their experiences and observations via YouTube. Drought is a slow onset natural phenomena with consequences that are visually impactful. ${ }^{5}$ Previously, it was only understood from the viewpoint of official, departmental reports and the hard facts gathered from these official documents. Social media, it is argued, can give the historian more personal insight into the impact of such phenomena and how they are experienced by the ordinary person. For this study the focus is on a random selection of videos from

1. Related to the use of theory by historians (not as in the social sciences) see A. Marwick, The Nature of History, 3rd ed. (MacMillan Education, Hampshire, 1989), pp 244-245.

2. Post-modernism touches upon the critique of histories, calling for a careful examination of all possible sources. See the preface in A. Marwick, The New Nature of History: Knowledge, Evidence, Language (Palgrave, Basingstoke, 2001), p xiii.

3. The author's research indicates that the history of drought has very little coverage on how people at ground level actually experience drought conditions. There are only a few academic studies which were undertaken in Australia and America. Most other research projects are based largely on official reports and look at how drought affects a particular country's economy, food supplies, etc. There is thus a need to investigate how drought conditions affect people in their personal capacity.

4. See for example the introduction of oral histories in Scotland, with the advent of postmodernism, as in A. Bartie and A. McIvor, "Oral History in Scotland", Scottish Historical Review, 92, 234(2013), pp 125-128.

5. Searching the term "drought" often brings forth images of desolation and death. The voices of those who face these real-life conditions on a daily basis are often neither heard nor studied. 
people who have commented via YouTube on their experiences of the drought from 2015 to 2017 in the Vaal Triangle. These insights are critiqued in an attempt to weigh the historical reliability of YouTube as source for the historian.

To do so, the discussion is opened with a literary overview of research that has made use of this medium (some of it critical) as well as a contextualisation of the use of social media (with emphasis on YouTube) in South Africa. It is suggested that YouTube as an audio and visual source may hold specific value for regional histories, especially in its contribution as a readily accessible source. Its critical evaluation in the ensuing section is thus drawn from the teachings of both oral and regional historians, but also inclusive of the aid of other disciplines with regard to video analyses. Lastly, the historical value of using social media as a source is "tested", as some of the YouTube videos are critiqued against the backdrop of contributing to an understanding of the 2015-2017 drought experienced in the Vaal Triangle. It is hoped that this study will assist the modern-day historian, as utiliser of sources in many formats, to begin understanding the ways YouTube, as a social media platform, can be used as both a primary and secondary source for historical research. As no clear methodology for the incorporation of social media exists as yet, this study serves as a point of departure to provide more depth and width in future historical studies.

\section{Social media in South Africa and historical research}

It is pertinent for any researcher to look into all available sources in the particular field under scrutiny. This study proposes nothing different in that regard, but advocates for the inclusion of social media, and specifically YouTube, in the spectrum of possible historical sources. In this section a discussion is provided on the available intellectual knowledge regarding social media in regional history; the context of social media and the use of YouTube by the general public in South Africa is also outlined briefly.

Considering the use of social media in historical research, the value of YouTube is perceived as two-fold: As a means to explore audio sources (capturing oral narratives on historical moments) and as a visual source (capturing visual moments) that remain open for individual interpretation. The following section looks at the literature that makes use of and advocates the incorporation of social media in historical research, both locally and abroad.

Diggs states that people are more prone to remember an event that is either recent or very severe. ${ }^{6}$ This is in line with Tosh's comments on the use of oral testimonies and the fallacy of memory. ${ }^{7}$ As such, among other uses, social media platforms such as YouTube play an important role in sketching and memorialising a vivid image and providing a real-time understanding of disaster situations. Drought,

6. D.M. Diggs, "Drought Experience and Perception of Climatic Change among Great Plains Farmers", Great Plains Research, 1, 1 (1991), p 122.

7. J. Tosh, The Pursuit of History: Aims, Methods, and New Directions in the Study of Modern History, 3rd ed. (Longman, Harlow, 2000), pp 194, 199. 
in turn, as a slow-onset disaster, is experienced differently throughout its stages of manifestation. YouTube in this case becomes a tool for preserving people's memories of drought events that historians, among other researchers, can utilise. Here the focus is on the use of YouTube in historical research and in this respect it was found that very little research has been conducted when combining a search for drought and social media, and even less so for studies pertaining to South Africa. ${ }^{8}$ In Table 1 an outline is given of some South African journals whose articles have made use of or made reference to either "social media", "YouTube", "Facebook", and/or "Twitter". None had a focus on drought per se. ${ }^{9}$

Table 1: Some South African history journals making use of, or reference to "social media", "YouTube", "Facebook" and/or "Twitter"10

\begin{tabular}{|l|l|l|l|l|l|}
\hline Journal title & Dating between & $\begin{array}{l}\text { Social } \\
\text { Media* }^{*}\end{array}$ & YouTube & Facebook & Twitter \\
\hline Historia & $1992(\mathrm{v} 37)-2017(\mathrm{v} 62)$ & 8 & 3 & 4 & 3 \\
\hline $\begin{array}{l}\text { Journal for } \\
\text { Contemporary } \\
\text { History }\end{array}$ & $2002(\mathrm{v} 27)-2017(\mathrm{v} 42)$ & 6 & 1 & 4 & 2 \\
\hline New Contree & $1996(\mathrm{n} 39)-2017(\mathrm{n} 79)$ & 3 & 2 & 1 & 0 \\
\hline $\begin{array}{l}\text { South Africa } \\
\text { Historical Journal }\end{array}$ & $2001(\mathrm{v} 44)-2008(\mathrm{v} 60)$ & 0 & 0 & 1 & 0 \\
\hline $\begin{array}{l}\text { South African } \\
\text { Journal of Art } \\
\text { History }\end{array}$ & $2006(\mathrm{v} 21)-2017(\mathrm{v} 32)$ & 24 & 10 & 14 & 4 \\
\hline $\begin{array}{l}\text { South African } \\
\text { Journal of Cultural } \\
\text { History }\end{array}$ & $2001(\mathrm{v} 15)-2017(\mathrm{v} 31)$ & 2 & 2 & 1 & 0 \\
\hline $\begin{array}{l}\text { TD The Journal for } \\
\text { Transdisciplinary } \\
\text { Research in } \\
\text { Southern Africa }\end{array}$ & $2005(\mathrm{v} 1 \mathrm{n} 1)-2017$ & 12 & 13 & 18 & 9 \\
\hline Yesterday \& Today & $1981(\mathrm{n} 1)-2017(\mathrm{n} 18)$ & 8 & 14 & 7 & 3 \\
\hline Total & & 63 & 45 & 50 & 21 \\
\hline
\end{tabular}

*Searched in both Afrikaans (sosiale media) and English (social media).

8. Sources with this combination include J.D.R. Sinoga and T.L. Gross, "Droughts and their Social Perception in the Mass Media (Southern Spain)", International Journal of Climatology, 33, 3(2013), pp 709-724; V.J. Shimpi and R.R. Ade, "Understanding the 2016 Drought in India by Social Media Data Mining", Communications on Applied Electronics (CAE), 5, 6(2016), pp 1-5.

9. An exception is the work by Schellnack-Kelly with her focus on environmental issues through indigenous knowledge discourse, making use of, among other mediums, digital technologies. See I. Schellnack-Kelly and V. Jiyane, "Tackling Environmental Issues in the Digital Age through Oral Histories and Oral Traditions from the iSimangaliso Wetland", Historia, 2 (2017), pp 112-129.

10. To learn whether modern historians have begun to include social media as a source in their research, the author has examined each of the mentioned journals carefully. The online journals were searched with the keywords: "social media", "sosiale media", "YouTube", "Twitter" and "Facebook". Also note the year of publication of each source. Because of the existence of social media prior to YouTube, the entire lifespan (as shown on the Sabinet system) of each journal was investigated. 
Literature on the use of social media as a tool for the dissemination of ideas, such as in drought reporting, and/or as a crisis communications tool, seems to have only begun to emerge in about $2010 .{ }^{11}$ Research in this field is therefore still relatively new, and thus full of explorative territory.

Additionally, from an international perspective, Kousha, Thelwall and Abdoli, with a focus on social media, and specifically YouTube, found in their study that researchers who make use of YouTube videos as part of their analyses vary greatly in discipline and topic. ${ }^{12}$ These range from the arts and humanities to social sciences, the natural and formal sciences, and the medical and health sciences. The natural and social sciences appear to take the lead in the use of social media as a source. Communication studies, information science studies and disaster risk research are also active in research on the usability of social media as a communication medium, particularly during disaster events. ${ }^{13}$ The communication capability of the internet has been of increasing interest to researchers in Germany, notably those of the Historical Social Research Focus. Another example is the work by Classen, Kinnebrock and Löblich which reflects on the importance of social media and the Web for historians. They claim it is an important source with regard to both availability of content and primary source material. ${ }^{14}$ The still limited use of social media by historians as a source may, it is suggested by some, be due to the reliability of the material, ${ }^{15}$ but also to an undue reliance on text-based sources by traditionalists.

11. This is noted in the short literature survey provided in Z. Tang, L. Zhang, F. Xu and H. Vo, "Examining the Role of Social Media in California's Drought Risk Management in 2014", Natural Hazards, 79, 1(2015), p 172.

12. K. Kousha, M. Thelwall and M. Abdoli, "The Role of Online Videos in Research Communication: A Content Analysis of YouTube Videos Cited in Academic Publications", Journal of the Association for Information Science and Technology, 63, 9(2012), pp 1710-1714.

13. Consider (among many others) B.R. Lindsay, "Social Media and Disasters: Current Uses, Future Options, and Policy Considerations", 2011, Congressional Research Service Washington DC, R41987; D. Yates and S. Paquette, "Emergency Knowledge Management and Social Media Technologies: A Case Study of the 2010 Haitian Earthquake", International Journal of Information Management, 31, 1(2011); and Tang, et al., "Examining the Role of Social Media".

14. C. Classen, S. Kinnebrock and M. Löblich, "Towards Web History: Sources, Methods, and Challenges in the Digital Age - an Introduction", Historical Social Research/ Historische Sozialforschung, 37, 4, 142 (2012), pp 97-98.

15. Consider M. Mendoza, B. Poblete and C. Castillo, "Twitter under Crisis: Can We Trust What We RT?", Paper presented at the first workshop on social media analytics (SOMA 2010), Washington DC, 25 July 2010, pp 75-77. 
Social media, also referred to as "new media" 16 (YouTube, Twitter or Facebook) is often contrasted with the more traditional form of media, appropriately named "old media" (such as newspapers). As to the use of "new media", McKee deliberates on the availability and ease of access of audio-visual sources from two possible repositories. ${ }^{17}$ These include YouTube as a potential source for historical inquiry as opposed to traditional film from the National Film and Sound Archive (NFSA) of Australia. In his study he maintains that YouTube provides more information of a popular history nature than that of NFSA sources, and points to an easier mode of access in the former. The competitive nature between "old media" and "new media" has also permeated into Germany. This came to the attention of German researchers in 2012 when they weighed news reportage through the more traditional newspapers versus the growing and ever-changing Web media in their country. ${ }^{18}$ Oggolder states that more research into the reliance and changing nature of news reportage is needed as technology and Web media develop. ${ }^{19}$

This is especially the case in the field of historical research where physical sources have always been highly appreciated and heavily relied upon. ${ }^{20}$ Schwarzenegger makes the point on the value of "new media", in particular regarding communications history. ${ }^{21}$ He emphasises the importance of "new media", not only as a new source for investigating societal interaction in the present generation, but also as a possible means of preserving the history of communities. Although Schwarzenegger's study focuses on the field of communication, it expresses a need to understand how future societies might well wish to look back to investigate our current generation. Contributions from both Australia and the USA on the experience of drought through oral history drew the researcher's attention to the gap in similar research in South Africa and the possibility of a historical study of the role of social media, and specifically YouTube, for filling this gap. ${ }^{22}$ This was especially so after

16. Some sources make the distinction between new media and "new" new media, with social media falling in the latter category, since the first wave of electronic media (Amazon and iTunes) from the 1990s was already regarded as new media. See P. Levinson, New New Media, 2nd ed. (Pearson, Boston, 2013), pp 2-3.

17. A. McKee, "YouTube versus the National Film and Sound Archive: Which is the More Useful Resource for Historians of Australian Television?", Television \& New Media, 12, 2(2011), pp 154-173.

18. C. Oggolder, "Inside - Outside: Web History and the Ambivalent Relationship between Old and New Media", Historical Social Research/ Historische Sozialforschung, 37, 4, 142 (2012), pp 134-149.

19. Oggolder, "Inside - Outside", p 136.

20. Consider the work by Sedrez in 1998; at this early stage he advocated the wide use of the internet in general. See L.F. Sedrez, "The Use of the Internet as a Source for Environmental History", Electronic Green Journal, 1, 8, at https://goo.gl/8KRPgU Accessed 31 October 2017.

21. C. Schwarzenegger, "Exploring Digital Yesterdays: Reflections on New Media and the Future of Communication History", Historical Social Research/ Historische Sozialforschung, 37, 4, 142(2012), pp 118-119.

22. S. Kite, S. Lemons, and S. Paustenbaugh, "Dust, Drought and Dreams Gone Dry: Oklahoma Women and the Dust Bowl Oral History Project", Oklahoma State University Library, c. 2002, at https://goo.gl/6SdPFs Accessed 1 October 2017; D. 
drought victims in South Africa turned to social media to share their experiences and plead for aid. ${ }^{23}$

Social media has not only led to more people being connected worldwide, but also to the spread of information in a more continuous stream from all walks of life. In this way regional histories also benefit, as is evident from existing research that thematically or regionally has a historic nature inclusive of social media, such as in the case of drought histories. Vogel and Van Zyl testify that people are experiencing drought differently as South Africa becomes more integrated with the technological advances of the 21st century. ${ }^{24}$ They highlight technology within the scope of social media as well as the increased mobility of the nation, which has also broadened the networking borders of those affected by drought. ${ }^{25}$ The concept of "region" as understood in its geographical sense may therefore also be viewed critically because considerations for social media posts contributing to regional history are investigated. In many instances the impact of drought also comes to bear on the region or the local community's economic and agricultural development. ${ }^{26}$ In addition, Sedrez speculates on the role of historians who, in contrast to climatologists, not only report on the statistics related to the phenomenon, but also seek the social side of space and time in the memories of those who have experienced past moments in many ways. ${ }^{27}$ This particular combination's association with social media seems to be limited in and on South Africa, especially as far as it concerns historical perspectives. To gain insight into the shared observations and experiences of societies, facets and themes such as drought are of great value and are integral to the development of spaces such as the Vaal Triangle.

Multidisciplinary studies are now making use of YouTube as an additional source, ${ }^{28}$ and there are a number of studies worldwide dealing with the perception

Connell, B Bunbury, R. Willis and R. Linn (interviewers), "Drought Oral History Project", National Library of Australia, Canberra, 2008, at https://goo.gl/7qi4PI Accessed 1 October 2017.

23. See for example a YouTube video post: Anon., "Boere in Nood", 8 January 2016, at https://www.youtube.com/watch?v=0oXBVCjWryw Accessed 28 June 2017.

24. C. Vogel and K. van Zyl, "Drought: In Search of Sustainable Solutions to a Persistent, 'Wicked' Problem in South Africa", in N. Salzmann, C. Huggel, S.U. Nussbaumer and G. Ziervogel (eds), Climate Change Adaptation Strategies: An Upstream-downstream Perspective (Springer, New York, 2016), pp 205-206.

25. Vogel and Van Zyl, "Drought: In Search of Sustainable Solutions”, p 204.

26. For example, O.P.J. Stander, "Die Voorkoms van Wit Armoede in Oudtshoorn tussen 1914-1937", PhD thesis University of Stellenbosch, 2017; and J.W.N. Tempelhoff, Townspeople of the Soutpansberg: A Centenary of Louis Trichardt (1899-1999) (Greater Louis Trichardt TLC, 1999).

27. L. Sedrez, "Of Water, Narratives, and the Uses of Environmental History", Rachel Carson Center, 2 August 2017, at https://goo.gl/ZYwCdg Accessed 27 October 2017.

28. See for example E.S. van Eeden, "Regional, Local, Urban and Rural History as Nearby Spaces and Places: Historiographical and Methodological Reflections", New Contree, Special Edition, 63 (2012), p 13. 
and experience of drought. ${ }^{29}$ Making use of YouTube to explore new themes in established research such as the indigenous knowledge systems of communities gives a new additional medium from which to explore oral histories. ${ }^{30}$ It is more than possible that memories on the circumstances of drought come to light in regional histories obtained from personal memories shared, for instance, via YouTube. This opens up a new historical method for interpreting the past, because YouTube becomes part of the discourse for, among others, regional historians.

\section{Social media with specific emphasis on YouTube}

Social media plays a profound role in connecting people because of its communicative capability. It refers to the way people socialise and communicate important, relevant information over the internet. Social media platforms such as YouTube, Facebook and Twitter give users the ability to extend their offline social networks with an online list of "friends" or indeed the general public. ${ }^{31}$ As such, on its various platforms, social media is increasingly being used as spaces where a vast number of ideas and impressions of phenomena are disseminated at an exceptionally high rate. Experts share information, natural scientists share their findings and ordinary people share their experiences. Social media provides the end-users with information at their own pace because information can be accessed whenever convenient. ${ }^{32}$ In YouTube, the feature of uploading videos is sometimes referred to as contributing to a "virtual repository", because it is a storage space for shared experiences "as they happen". 33

YouTube was founded in 2005 by former PayPal employees Chad Hurley, Steve Chen and Jawed Karim and was introduced to the public on 15 December of the

29. Among these works are D.L. Woudenberg, D.A. Wilhite and M.J. Hayes, "Perception of Drought Hazard and its Sociological Impacts in South-Central Nebraska", Great Plains Research, 18, 1 (2008), pp 93-102; B. Mandleni and F.D.K. Anim, "Perceptions of Cattle and Sheep Farmers on Climate Change and Adaptation in the Eastern Cape Province of South Africa", Journal of Human Ecology, 34, 2 (2011), pp 107-112; B. Hunter, M. Gray and B. Edwards, "The Use of Social Surveys to Measure Drought and the Impact of Drought", Social Indicators Research, 113, 1 (2013), pp 419-432; Y.T. Bahta, A. Jordaan and F. Muyambo, "Communal Farmers' Perception of Drought in South Africa: Policy Implications for Drought Risk Reduction", International Journal of Disaster Risk Reduction, 20 (2016), pp 39-50; and Z.A. Elum, D.M. Modise and A. Marr, "Farmers' Perception of Climate Change and Responsive Strategies in Three Selected Provinces of South Africa", Climate Risk Management, 16(2017), pp 246-257.

30. N. Wachowich and W. Scobie, "Uploading Selves: Inuit Digital Storytelling on YouTube", Études/Inuit Studies, 34, 2 (2010), pp 81-105.

31. S. Hinton and L. Hjorth, Understanding Social Media (Sage, London, 2013), p 1.

32. Levinson, New New Media, p 9. The ability to keep data available in perpetuity on the internet has, however, been contested.

33. S.J. Derry, R.D. Pea, B. Barron, R.A. Engle, F. Erickson, R. Goldman, R. Hall, T. Koschmann, J.L. Lemke and M.G. Sherin, "Conducting Video Research in the Learning Sciences: Guidance on Selection, Analysis, Technology, and Ethics", The Journal of the Learning Sciences, 19, 1 (2010), p 30. 
same year. ${ }^{34}$ More than 10 years later, South African usage of this platform has grown significantly. In 2015, the status of YouTube usage in South Africa was 8.2 million users, and by 2016 this number had increased by $15 \% .{ }^{35}$ With its slogan of "Broadcast yourself", YouTube is better known for its contribution to the world of entertainment but it also gives ordinary people the opportunity to report on events as they experience them. Added to this is the possibility of giving viewers a glimpse into the lives of others in an audio-visual format rather than describing it through text; words can be ambiguous and are easily misinterpreted.

With the increase in mobile device technology, YouTube users can post videos mere seconds after they have been observed, and since April 2011 they have been able to broadcast their videos "live". ${ }^{36}$ This gives YouTube users the opportunity to report on historically significant events in real-time, ${ }^{37}$ such as their observations of the $2015-2017$ drought in South Africa. Real-time reporting thus becomes a possibility and researchers are able to catalogue people's views and experiences almost as diary entries. As is the case with other social media platforms, YouTube allows us to investigate social interactions and people's role in events as they happened - even if the investigation is only launched years after the event actually took place.

\section{Attempting a historical method for incorporating YouTube as a source}

In addition to the large repository of sources available on YouTube, social media can also give a timestamp and, if the provider of the information allows, an exact geographical location. ${ }^{38}$ It is true to say that the internet, and social media provide a new line of research for studying 21st century society. ${ }^{39}$ Audio-visual sources such as YouTube videos serve as valuable representations of the past and allow for the study of social interactions as they unfold. ${ }^{40}$ YouTube is particularly relevant as a

34. M.R. Dickey, "The 22 Key Turning Points in the History of YouTube", Business Insider, businessinsider.com, posted on 15 February 2013, at https://goo.gl/nZGjDV Accessed 26 May 2017.

35. J. McEndoo, "The State of Social Media in South Africa 2015", BlueMagnet, at https://goo.gl/o9i28L Accessed 22 April 2017.

36. Dickey, "The 22 Key Turning Points in the History of YouTube".

37. Real-time means "in the present".

38. This is otherwise referred to as geotagging and is often visible on social media platforms such as Facebook and Twitter.

39. P. Uimonen, "Internet and Social Media: Anthropological Aspects", in J.D. Wright (ed.), International Encyclopedia of the Social \& Behavioral Sciences, 2nd ed. (Elsevier, Amsterdam, 2015), p 601.

40. S. Gunn and L. Faire, Research Methods for History (Edinburgh University Press, Edinburgh, 2012), at https://goo.gl/jK2WCK pp 30-31, Accessed 9 August 2017; H. Knoblauch, B. Schnettler, J. Raab and H-G. Soeffner, Video Analysis: Methodology and Methods, Qualitative Audiovisual Data Analysis in Sociology (Peter Lang, Frankfurt am Main, 2012), at https://goo.gl/x6XS6e, pp 9-10, Accessed 1 November 2017. Schnettler and Raab are also of this opinion, especially regarding the fields of social sciences and the humanities. See B. Schnettler and J. Raab, "Interpretative Visual 
contribution to regional history. ${ }^{41}$ For the historian, however, YouTube has to be assessed with the utmost care because it requires, perhaps more than ever before, robust internal and external source criticism before value judgement can be made. As such, the methodology must be guided by the historical method, and complemented with some very specific requirements in branches of history such as regional history (closely connected with social histories, cultural and heritage studies ${ }^{42}$ and affectiveemotional ${ }^{43}$ related studies in history), as well as oral history.

Multiple studies outside the research domain of History were consulted to gain a better understanding of the use and interpretation of audio-visual material. ${ }^{44}$ This was done in order to formulate a methodology for the interpretation of YouTube videos as a source material, but also as a means to critically assess its historical value. The basic interpretation of the material for this study leant itself to a qualitative historical interpretation. Key among contributors from the field of the discipline of History are Van Eeden, with her extended model framework for the interpretation of regional histories. ${ }^{45}$ The works by Leavy and Tosh were explored because they provide insight into the interpretation of oral sources which contributes to the capture of memory. ${ }^{46}$ Along with the publication by Tosh, Marwick's Nature of History (1989) was particularly useful on the issue of source criticism. ${ }^{47}$ To a lesser degree, the insights of social scientists for the interpretation of the YouTube videos as audiovisual material were derived from Knoblauch et al. ${ }^{48}$ At this stage, criteriaidentification assisted in helping to minimise the number of elements (that is respondents) to be studied. Krippendorff highlights the importance of respondents sampled from a group who remain representative of the particular group and not a whole population; ${ }^{49}$ a response with which most historians concur. ${ }^{50}$

Analysis Developments: State of the Art and Pending Problems", Historical Social Research/ Historische Sozialforschung, 34, 2, 128(2009), p 272.

41. See B. Allen and W.L. Montell, From Memory to History: Using Oral Historical Sources in Local Historical Research (American Association for State and Local History, Nashville, 1982). The value of oral history research projects was also investigated, especially as linked to regional histories. See for example D. du Bruyn, "Oral Testimonies as a Source of Community History, with Special Reference to the Batho Project, Bloemfontein", South African Journal of Cultural History, 24, 2(2010), pp 1-24.

42. E.S. van Eeden, "Challenging Traditional Ways of Thinking and Doing Local/Regional History Research in South Africa: Some Global Learning and Sharing", International Journal of Regional and Local History, 9, 1(May 2014), pp 27-43.

43. S.A. Oushakine, "Remembering in Public: On the Affective Management of History", $A b$ Imperio, 1(2013), pp 269-302.

44. Among these are the fields of Communication Studies and the social sciences.

45. Van Eeden, "Regional, Local, Urban and Rural History", pp 25, 28-31.

46. P. Leavy, Oral History: Understanding Qualitative Research (Oxford University Press, Oxford, 2011) at https://goo.gl/hZQNYL Accessed 18 November 2017; and Tosh, The Pursuit of History, pp 193-210.

47. Marwick, The Nature of History, pp 193-234, 284-327.

48. Knoblauch, et al., Video Analysis, pp 1-10.

49. K. Krippendorff, Content Analysis: An Introduction to its Methodology (Sage, Los Angeles, 2013), pp 120-121. 
Based on Van Eeden's framework, aspects were identified to guide this study and define a suitable methodology. ${ }^{51}$ The Vaal Triangle is considered as a space and/or place, with drought as the overall focus of investigation. The public observations and experiences of ordinary people as expressed via YouTube - how they reacted to these drought conditions, is then assessed. The videos reflect a record of the people's physical experience but also their sense of space and place because the views were considered from a methodological bottom-up approach. By connecting the oral testimonies of ordinary people as shared through YouTube, the study refocused the perspective of drought, deviating from a traditional top-down view ${ }^{52}$ to a more bottom-up view. ${ }^{53}$

It was also necessary to determine whether the respondents reflected on, for example, development and change or simply recorded their physical experience. As such, Van Eeden's approach was used to assess whether the respondents placed themselves within (or as a part of) the space known as the Vaal Triangle, especially in terms of the theme of drought and their experience of these conditions. The drought in this instance serves as a memory trigger. Aspects of tone, emphasis and emotionality during the sharing of memory on drought serve as some of the criteria by which to understand YouTube audio from the methodology of oral history, but can also serve as added source criticism. ${ }^{54}$ Leavy also mentions three aspects oral historians consider that are applicable in this study, namely the detection of a "moral language", the presence of "meta-statements" and the "logic of the narrative". 55 The editing of video material may in this sense influence these aspects, as well as the total lack of communication, which also influenced the function of the video. This functionality is explained in the ensuing paragraphs.

Criticism by Marwick and observations by Tosh on some aspects of historical inquiry were adapted for the interpretation of the videos (inclusive of both their content and their commentary). While Marwick reflects on internal and external source criticism, it was of value (due to the possible anonymity of respondents) to

50. Consider Marwick's comparison of the practices of historians and scientists in terms of the use of theory in Marwick, The New Nature of History, pp 247-248.

51. See the academic articles by Van Eeden, "Regional, Local, Urban and Rural History", p 31; and Van Eeden, "Challenging Traditional Ways of Thinking and Doing Local/Regional History Research", pp 35-39.

52. A top-down perspective may, however, be present where an institution/organisation/ political institution has posted on the drought, depending on the function of the video.

53. As in a quotation by P.M. Katz cited in Van Eeden, "Regional, Local, Urban and Rural History”, p 32. Van Eeden also deliberates on regional history's ability to bring the experiences of ordinary people to the fore without turning the information into a parochial anecdote that only adds to local knowledge.

54. Leavy, Oral History, p 28.

55. Leavy, Oral History, pp 47-48. Moral language refers to the person's self-identity or moral values. Meta-statements are those which reflect an attempt to either correct or emphasise what was said. Logic of narrative is somewhat self-explanatory, but relies upon whether the researchers can make sense of what they are being told. 
also criticise the videos in terms of their possible function. These functions are derived from criteria touched upon by Knoblauch, Schnettler, Raab, and Soeffner. ${ }^{56}$ These criteria include what can be deduced from the videos in terms of possible meaning behind the videographer's recording as well as the likely meaning behind the edited videos. The influence of the videographer's choice in method as well as manner of recording, e.g. a testimonial of a drought-stricken citizen, ${ }^{57}$ will provide more information than the drone footage of an empty dam with no commentary. ${ }^{58}$ The extent of editing of his or her recording is also of interest, as is how this affected the function and, more importantly, the reliability of the video. This was kept in mind when the researcher interpreted the videos and their contribution to the oral and regional history of the drought affected area.

In addition to understanding the function of a video, the reason for posting it also had to be considered. Although it is indeed true that the ultimate function may not be known to the viewer, the author of this article based her assumptions on what data could be gathered from each video and then categorised them accordingly. In the study by Tang et al., the function of social media posts form an integral part of their study. ${ }^{59}$ The main functions identified were: communication as one-way information sharing; and communication as two-way information sharing. Also important were sharing situational awareness, rumour control, reconnection, decision-making, donation soliciting and volunteer management. In the case of South Africa, some of these functions were more apparent in social media such as Facebook and Twitter with "soliciting donations" and "volunteer management" functions identifiable.

This current study identifies functions of the YouTube videos that speak to the social interaction of society at large ("to manage", "to engage"), but also help to understand how and possibly why individuals chose to share their experiences. This depends on what they reported about their experiences ("to inform", "to share"). In more detail, "to inform" refers to authorities notifying the public on the stance of the drought, as well as public users updating people of the stance of their individual drought situations. "To share" considers the public relaying information generated elsewhere as well as the personal experiences of the drought that are forwarded (in other words the information and experiences not created or experienced by themselves). "To engage" is interpreted as when stakeholders talk among themselves while they cope with the drought. "To manage" refers to the management of drought relief strategies used. In some cases, these functions may overlap somewhat.

A further requirement may be to look into the quantitative information to gain a full appreciation of the sources' historical contribution. Several social studies make

56. Knoblauch, et al., Video Analysis, pp 9-10.

57. D. Grobler, (posted 13 September 2016), "The Vaal Dam - 2016 Drought", at https://www. youtube.com/watch?v=UCA8X0HRxgM Accessed 28 June 2017.

58. See A. Dadabhay, (posted 9 October 2016), "The Vaal Dam - 29\% Water Level, Save Water, Drone Footage", at https://www.youtube.com/watch?v=NKLpYTz4Lac Accessed 22 June, 2017.

59. Tang, et al., "Examining the Role of Social Media", pp 171-172, 174. 
use of data-mining techniques as a means of processing content for quantitative and qualitative research purposes. Some of these methods may include the evaluation of YouTube-related statistics involving the number of posts made, viewed and shared. These can be reviewed in terms of their reliability and usefulness as a historical source. However, due to the growing awareness of "click-bait" posts, ${ }^{60}$ these statistics have proven less important as a contributory factor to the qualitative interpretation of people's past drought experiences and understanding their historical value.

On the other hand, by making use of the audio-visual information and the commentary in each video, this study extends itself to a qualitative research study as well as one that engages in tangible content analysis. Based on this qualitative approach, Lester's understanding of phenomenological research was used as a means of guiding the interpretation, analysis and reporting of information, ${ }^{61}$ resulting in an analysis of and an understanding of a historical moment based on the shared experiences of individuals. The identified YouTube video posts on drought were further categorised according to themes of focus, namely political, theological, agricultural, environmental, economical, infrastructural and/or general groupings. ${ }^{62}$ In retrospect, it may have been more apt to allow the data to speak for itself rather than predetermining the themes. However, from the guiding research model for regional history outlined by Van Eeden these themes are viewed as contributory to any study of regional history. ${ }^{63}$ Within these categories, aspects of homeliness as a part of a sense of emotional connectedness and subsequent experience of drought added to the richness of oral history within regional historical studies.

The contribution of oral testimonies in the social media as a means of gaining a clear understanding of the circumstances and experiences of past phenomena is significant, albeit that close critique practices must be followed. The time lapse of oral history has however been a concern to historians because the accuracy in recalling events as they occur is often debated. ${ }^{64}$ Oral histories should be recorded as close as is feasible to the time period of the event investigated, so as to minimise the impact of "false", vague or changed memories. This aspect in itself speaks to the shared experiences and perspectives of the audio-visual information in the YouTube videos of both institutional and individual posts. As mentioned before, aspects of tone,

60. 'Clickbait' aims to attract as much attention from internet users as possible and encourages them to click on advertisements, etc. Income is generated by the number of times people click on certain ads on the internet, thus the "bait" concept.

61. S. Lester, "An Introduction to Phenomenological Research" (Stan Lester Developments, Taunton, 1999), at https://goo.gl/rQLcij , pp 1-4, Accessed 9 April 2017.

62. Lester's phenomenological research approach also advocates this line of inquiry in qualitative research. See *Lester, "An Introduction to Phenomenological Research".

63. Van Eeden, "Challenging Traditional Ways of Thinking and Doing Local/Regional History Research", pp 27-43; and Van Eeden, "Regional, Local, Urban and Rural History", p 31.

64. Tosh highlights such misgivings felt by historians who initially criticised the "hindsightedness" of oral testimonies. See Tosh, The Pursuit of History, p 194. 
emphasis and emotionality during the sharing of a memory and/or experience are relevant in understanding the contribution of YouTube from an oral history methodology. ${ }^{65}$ Recording (and perhaps also sharing) experiences within the timeperiod of the phenomenon being investigated make such recordings primary source material. ${ }^{66}$ It is still, however, important to consider that the respondents in such a study may not reflect deep-seated knowledge on a certain event, such as drought, in the specific region investigated. ${ }^{67}$ However, the use of YouTube may presently, and in future, become an effective tool for historians to better understand the role the ordinary person (or people as a collective) play in the development of a region before, during and after disaster situations such as drought.

\section{YouTube as a historical source on the drought experienced in the Vaal Triangle}

It has been established that the way members of society perceive and relate their experiences is central to their relationship and use of technology, and more specifically social media such as YouTube. Using a social media platform such as YouTube as a tool in this study of region-specific research, ${ }^{68}$ serves as a means to capture the impact of the drought on the local inhabitants and the development of their area over time. For the purposes of this section a short description into the method of data-gathering and analysis for this study is provided.

Within the timeframe of one month, from June 2017 to July 2017, there were 570 YouTube videos posted across South Africa on the severe drought conditions in the period 2015-2017. Of these, 32 focused specifically on the Vaal Triangle area. This information was extracted with a keyword search of the term "Vaal" for the columns of "Titles" and "Descriptions", in an Excel document where the data were sorted and stored. The basis on which the final videos were chosen relied on the amount of "views" and/or "comments" each obtained from the viewers. The first ten of those with the most "views" and/or "comments" were selected, ${ }^{69}$ after which five of the most relevant were chosen for analysis.

It may be in this process that the researcher's discretion could potentially lead to bias, although it is accepted that no research study is completely without bias. This method of choosing the videos has meant that some of the videos were posted by the same producer. The researcher did not completely exclude such videos from analysis

65. Leavy, Oral History, p 28.

66. Marwick advocates for oral sources to be recorded as close to the time of their occurrence as possible. See Marwick, The Nature of History, p 199.

67. See Heathcote's wariness in investigating people's perception and understanding of drought in R.L. Heathcote, "Drought in Australia: A Problem of Perception", Geographical Review, 59, 2 (1969), pp 175-176; and R.L. Heathcote, "Drought in Australia: Still a Problem of Perception?”, GeoJournal, 16, 4 (1988), p 387.

68. On region-specific research, see Van Eeden, "Regional, Local, Urban and Rural History", pp 1-33.

69. It has already been noted above that a choice in video for analysis by these means may not necessarily be the best course of action for a historian. 
when YouTube as a possible source for historical inquiry was reviewed. These videos could possibly reveal the presence of a historical consciousness whether or not the drought of 2015-2017 was experienced based on the memory of previous drought and/or flood events within the Vaal Triangle. Although no follow-up interviews were held, the social media posts were analysed with the purpose of delineating their feasibility and worth as a source for historical inquiry based on their contribution as audio-visual sources.

The Vaal Triangle as a regional history case study and the drought of 20152017

The Vaal Triangle, a key industrial area of the South African economy, is situated in the Highveld summer rainfall eco-region along the banks of the Vaal River. Its imaginary "borders" extend over the provinces of Gauteng and the Free State and the area includes the major towns of Vereeniging, Vanderbijlpark and Sasolburg (see Figure 1 below). Some sources differ in defining these borders, depending on their focus and discipline. For the purposes of this study the Vaal Triangle served as the case study area. According to the 2011 census, the area comprises more or less $424.59 \mathrm{~km}^{2}$ with a population density of 226326.70

Figure 1: Google Earth image of the Vaal Triangle with the Vaal Dam to the south-east

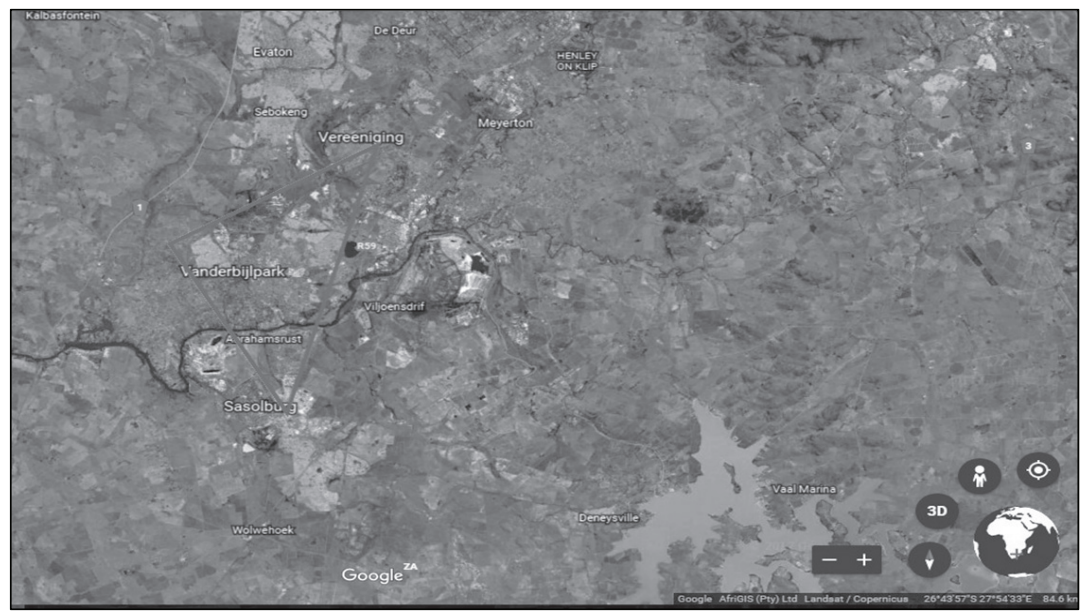

Source: Google Earth Image, 27 October 2017.

The drought experienced in the Vaal Triangle also covered a much larger portion of South Africa, and its onset can be dated back to 2013 in the North-West

70. StatsSA, "Census 2011", at http://www.statssa.gov.za/?page id=3839, Accessed 24 June 2018. 
Province. ${ }^{71}$ The Vaal Triangle has a ready supply of water from the Vaal Dam which is part of the intricate Integrated Vaal River System, and the effects of the drought only really became apparent to residents when water restrictions were imposed in $2015 .^{72}$ Lower dam levels soon became a constant and visible concern to those visiting the Vaal Dam and its lowest measurement was recorded in November of 2016 when its capacity dropped to 26.6 per cent. ${ }^{73}$

In a study region such as the Vaal Triangle, measuring the effects of the drought is problematic because sources reporting on the effects of the drought do not necessarily fall within the "borders" of the Vaal Triangle per se; they may include information for either the immediate surrounding provinces, water management areas, larger municipalities, and/or towns close to or related to the area under study. In most instances social media is able to overcome this issue with geotagged posts, but YouTube videos as well as their comments are yet to have this automated feature. ${ }^{74}$ This means that to identify specific geographical areas, the researcher had to rely on the descriptions of each post and evaluate its reliability with what was actually visible on each video. This formed part of the first phase of internal source criticism. Although the study was limited to the years 2015 to 2017, the progression of the drought at its various stages of severity were noted to correspond with the amount of social media "traffic", 75 likewise with YouTube.

In addition, the Vaal Dam feeds water to the surrounding areas and this water supply is central to their development. Built in the $1930 \mathrm{~s},{ }^{76}$ the presence of the dam has had an enduring impact on the perception of drought among the locals of this area. An analysis of the five selected videos also brought to the fore that the residents of urban areas linked their water security to the level of water in the local dam from which their water was and still is obtained. Rarely, however, was notice taken of the water service provider, namely Rand Water. Most of the urban water users (or at least those who posted their views online) did so when the effects of drought began to be noticed in their respective towns. This was due largely to lowered water pressure from the main water service provider, an issue that caused some high-lying areas to be without water altogether.

The low pressure elicited a lack of understanding (and thus possible misrepresentation) on the part of the residents. Respondents also showed an inclination to seek divine intervention by holding prayer meetings during the

71. S. Cilliers, "Droogte: Boere in NW Kry Hulp", Beeld, 23 December 2013, p 11; S. Kings, "Full Horror of Drought Emerges", Mail \& Guardian, 29 January 2016, p 17.

72. Bloomberg, "Farms Face Water Cuts", The Citizen, 3 November 2015, p 21.

73. S. Jimta, "Water Levels Critical!", Daily Sun, 3 November 2016, p 6.

74. Some social media platforms allow users to include their specific geographic location information with their posts on the web.

75. "Traffic" in this sense refers to the amount of posts made on a particular topic at certain points in time.

76. L. van Vuuren, In the Footsteps of Giants: Exploring the History of South Africa's Large Dams (Water Research Commission, Gezina, 2012), pp 134-137. 
drought. This is no new phenomenon as even in the 19th century, days of prayer were held for drought-stricken regions in the area. ${ }^{77}$ Of note was also that most of the videos carried the function of "to share" and were therefore not necessarily conveying the respondents' own personal struggles with the drought. There may be various reasons for this observation, one being the choice of videos for analysis. This represents only one of the difficulties that may arise in the use of YouTube as source material for historical analysis. In the next section some similar experiences in the research process are discussed.

\section{Reasoning the usability and reliability of YouTube as a historical source}

No study is without its inherent difficulties. However, the lack of a methodology for the incorporation of audio-visual material from social media in the form of YouTube in historical research poses a risk. This section reflects on the videos selected for analysis based on the means of critique outlined above. ${ }^{78}$ Complications and observations from the research process are also presented as a means to weigh reliability.

In the past, social media platforms such as YouTube were all seen as openaccess domains. Anything and everything posted was assumed to be open for interpretation unless the creators or registered users of the platforms had specifically stated that the material should not be freely used. However, the researcher has now been made aware that some recent sources state that the consent of the registered user/creator is required. ${ }^{79}$ This presents the first hurdle for researchers who wish to explore this line of research - the lack of a clear understanding of what type of information and what level of ethical clearance is called for. This situation appears to be changing on a daily basis as new ethical issues are brought to the fore. One such example is the anonymity of the individuals in the videos, who, by posting on a public media site, it is argued, effectively put themselves up for participating in research studies, regardless of their pseudo identities. ${ }^{80} \mathrm{In}$ other words anonymity is the

77. C. Gouws, "Vestiging langs die Vaalrivier in die Omgewing van die Vredefortkoepel, 1840-2012", PhD thesis, North-West University, 2013, p 247.

78. These include: SABC Digital News, "Water Released in Sterkfontein Dam to Boost Levels at the Vaal Dam", at https://www.youtube.com/watch?v=ZttqF9KXNtI Accessed 22 June 2017; Grobler, “The Vaal Dam - 2016 Drought”; D. Grobler, "Vaal Dam 4 (at 100\%) in 4K", at https://www.youtube.com/watch?v=smWeC62rauo Accessed 22 June 2017; Dadabhay, "The Vaal Dam - 29\% Water Level”; C. Griessel, "Water Crisis Vaal Dam - 11 October 2016", at https://www.youtube.com/watch?v=5FVmTXDGGc8 Accessed 22 June 2017.

79. The reason for this is ethical in nature and not necessarily from a legal perspective, because social media legislation is still evolving and does not reflect coherence across various countries. See K. Beninger, A. Fry, N. Jago, H. Lepps, L. Nass and H. Silvester, "Research Using Social Media: Users' Views", NatCen Social Research (2014), pp 2-3; P. Nyoni and M. Velempini, "Data Protection Laws and Privacy on Facebook", South African Journal of Information Management, 17, 1 (2015), pp 2-5.

80. This understanding has been deliberated by researchers and ethical considerations in recent publications. See E. Laurier, "YouTube: Using Third Party Video as Research Data", Unpublished paper, University of Edinburgh, School of GeoSciences, at https://goo.gl/ENLnqZ pp 9-10, Accessed 11 October 2017; L. Townsend and C. 
responsibility of the person posting the video and not that of the viewers, or in this case the historian. ${ }^{81}$ For this study the experience was that those who post the videos on YouTube tend to use their real names, if not that of the organisation they represent, either within descriptors such as the title, or within the video itself. ${ }^{82}$ Furthermore it is the responsibility of the users to stipulate (either as a disclaimer or within the description settings) for posts made, whether or not content may or may not be used for research purposes. In this study, none of the respondents' posts made viewers aware of such limitations.

This aspect is of some considerable concern, especially as it is not only the creator of internet-based content who can now potentially hinder historical research, but also the security policies of social media sites that have recently come to the fore. ${ }^{83}$ This is entrenched in the fact that anything posted online may at any moment be removed by the owner of the post and/or the social media platform managers. This gives YouTube and posts on other platforms a contemporary importance. Although they may act as repositories of information, due to the threat of, among other things, viruses, posts may be removed before researchers have been able to access and analyse them. ${ }^{84}$ Some historians have for a considerable time been aware of the ephemeral nature of internet-based sources. ${ }^{85}$ It is here that Sedrez's comment of "history hacker[s]", and "cyber-archaeologists" trained to investigate personal hard disks, among other things comes in. ${ }^{86}$ As "cyber-diggers" of the past, historians need to seek ways to work past these shortcomings as soon as possible. The impact of security measures speaks to the limits that the 21 st century historian is faced with. It expresses, in other words, a kind of digital ethical censorship that might just hinder future societies from understanding current societies. Furthermore, posts that are removed after a researcher has already accessed and referred to them may also bring their results into question. The storing of such posts, whether through downloading and fully inventorying them, may be the only way to avoid research results falling into disrepute.

This highlights the concern regarding the actual use of social media by the general populace. Time and space in the experience of phenomena such as drought

Wallace, "Social Media Research: A Guide to Ethics", Unpublished paper, University of Aberdeen, Economic and Social Research Council, 2016, pp 5-8.

81. However, these considerations have come under scrutiny; various loopholes allow the identity of any post to be traced with even a limited amount of skill in operating computer software. See Beninger et al., "Research Using Social Media, pp 25-28.

82. See SABC Digital News, "Water Released in Sterkfontein Dam to Boost Levels at the Vaal Dam”; Griessel, "Water Crisis Vaal Dam - 11 October 2016”.

83. Consider Facebook's policy to remove all material of a sensitive nature and the impact this may have on say histories of violence.

84. The "Achilles' heel" of YouTube videos (especially for researchers) lies in the potential removal of videos by those who have posted them. See also Levinson, New New Media, pp 58-61.

85. Note the argument put forward by Sedrez, "The Use of the Internet as a Source for Environmental History".

86. Sedrez, "The Use of the Internet as a Source for Environmental History". 
are regarded as a contributing factor for the current study. The fact that droughts occur at different time-scales and in different regions is of significance in terms of the society experiencing them. The issue of the digital divide also presents itself in South Africa and in this study. ${ }^{87}$ It is only recently that South Africans have had reasonable access to facilities for real-time mass reportage on a phenomenon such as a typical drought situation. The effective use of social media during, for example, the 20152017 drought crisis in South Africa could pose a problem. Not only will it be impossible for countries or regions with no internet access or the required technology to contribute to a study such as the one suggested, but people who refrain from making use of social media will not be able to add their voice. ${ }^{88}$

This was patently evident with the drought in question in that no YouTube reportage at all came from residents in the informal settlements on the fringes of the larger towns of the Vaal Triangle. Added to this is the slow-creeping nature of drought and the delayed impact thereof on human consciousness. This may also have influenced mass reporting through social media, especially in its early phases. Social media posts were observed to increase throughout the country as the severity of the drought increased. A type of chain reaction of awareness snowballed gradually throughout the social media. This effect is also under critique because over saturation of news often leads to a misrepresentation or rather over-representation of the true situation. Furthermore posts and videos tend to be lost in the maelstrom of posts made on social media platforms. ${ }^{89}$ For the Vaal Triangle almost the opposite seemed to be the case, with far less coverage in social media on the impact of the drought in the surrounding regions. As mentioned above, this may have been due to the sound management of the Integrated Vaal River System, which meant that people felt more secure of water availability.

Of the themes and functions identified earlier, the videos under scrutiny indicate a prevalence of environmental concern that spills over into theological muses of prayer, infrastructural connotations with reference to the Vaal Dam, as well as an economic focus on the impact of the drought. Griessel's video conveys a message calling for environmental concern as well as a sense of community and homeliness; a

87. On the problem of the digital divide between Third World and First World countries and the impact this has on social media use, see A.M. Kaplan and M. Haenlein, "Users of the World, Unite! The Challenges and Opportunities of Social Media", Business Horizons, 53, 1(2010), p 67.

88. Social media usage may differ based on economic, social and cultural aspects. This is highlighted by T.S. Aisha, S. Wok, A.M.A. Manaf and R. Ismail, "Exploring the Use of Social Media during the 2014 Flood in Malaysia", Procedia: Social and Behavioral Sciences, 211 (2015), p 932.

89. The options on YouTube are more user-friendly and allow one to find a video again with relative ease. An author in agreement with this is McKee, "YouTube versus the National Film and Sound Archive", p 170. 
shared responsibility for water conservation is advocated. ${ }^{90}$ This sense of concern is observed by both Griessel and Grobler; they place themselves historically in the area through a sense of community and memory recall respectively. ${ }^{91}$ The holding of prayer days for drought-stricken areas as mentioned earlier, are especially evident and hopes for rain are shared. The impact of the drought on the farming community and the local Deneysville tourist sector are also aired, for example in Grobler's video and the accompanying commentary. ${ }^{92}$ Both Grobler's videos convey information gathered elsewhere and hus fall into the functional category of "to share". ${ }^{93}$ However, due to the nature of his video, showing his viewers the economic impact of the drought in the Deneysville area in the vicinity of the Vaal Dam, they also take on the function of "informing". 94

Furthermore, the Griessel and Grobler videos are emotionally charged through the dialogue they share. Some historians may debate the historical value of this. However, as expressed in Oushakine's argument on public remembrances which capture emotions through "historical images, sound, or objects", YouTube may very well become a medium where the emotive connection that ties people to past experiences can be explored for 21st century societies. ${ }^{95}$ On the other hand, the video posted by Dadabhay contributes very little to a historical understanding of the drought. ${ }^{6}$ For the most part it only provides some keen video footage of the state of the Vaal Dam at a certain point in time. This is an example of a video that may not be of much value for the historian. Its perceived function may however be that of "to inform", because it shows a pictorial understanding of the drought's prolonged impact on the dam. Oddly enough, none of the videos have any political comment, which often seems to be the case in a country in the grip of prolonged suffering.

Lastly, an aspect that poses some difficulty relates to the method of recording. The historian has to rely on what had been posted on YouTube. There is neither a sense of control over the format and choice of recording device, nor of what is being said, if indeed, anything at all was said. Additionally, by making use of videos with the

90. Earlier mention of the themes identified include political, theological, agricultural, environmental, economical, infrastructural and/or general aspect. Functions included "to share", "to inform", "to engage" and "to manage".

91. To understand the context, consider Riukulehto's understanding of homeliness and regional identity: " $[\mathrm{A}]$ lthough regional identity is a social phenomenon, it is originally constructed on the personal level in a process where historical consciousness [plays a] central role." See S. Riukulehto and K. Rinne-Koski, "Historical Consciousness and the Experiential Idea of Home", in S. Riukulehto (ed.), Between Time and Space (Cambridge Scholars' Publishing, Newcastle, 2015), pp 115-134.

92. Grobler, "The Vaal Dam - 2016 Drought"; Grobler, "Vaal Dam 4 (at 100\%) in 4K".

93. "To share", as explained above, refers to the public relaying information generated elsewhere as well as personal experiences of the drought forwarded, therefore the information and experiences not created or experienced by themselves.

94. This implies notifying the public on the stance of the drought, as well as public users updating people of the stance of their individual drought situations.

95. Oushakine, "Remembering in Public", p 274.

96. Dadabhay, "The Vaal Dam - 29\% Water Level”. 
most YouTube "likes", "sharing", "views" and "comments" the current study runs the risk of viewing multiple videos from the same source, or videos that are not of historical import and possibly subject to "click-bait". Although no sample size is truly representative of the whole, a reliance on only one source for interpretation could skew the analysis. Added to this, videos that appear to have been practised or rehearsed before being recorded (those that are not "live" recordings) may not be credible as primary sources and this casts doubt on their authenticity. This consideration will require a more in-depth investigation of the field of audio-visual analysis, such as in the social sciences and in communication studies. Jewitt warns that the researcher also runs the risk of interpreting content that was shared within a certain historical context. ${ }^{97}$ The initial purpose, identified as the function for this study, as well as the potential intended audience of the video, need to be taken into account when the interpretation process begins. In retrospect, follow-up interviews may help to provide insight into the meaning behind certain aspects that are shared. The use of YouTube videos also distances the researcher from the respondents, especially as it is sometimes impossible to do follow-up interviews. ${ }^{98} \mathrm{As}$ historians, however, this hurdle is often a reality in the sources left behind to investigate. YouTube could perhaps then pose as a "mnemonic object" precisely because of its ability to share the emotive value of past moments audio-visually. ${ }^{99}$

\section{Conclusion}

Although all the remarks in this discussion may deem the use of YouTube as a historical source an almost impossible task, redolent with many risks, the very nature of its "openness" and usability makes it an ideal platform from which to study societies from more than just one given perspective. In the 21st century, observations on natural phenomena such as drought become part of collective memory; they are shared by ordinary people on a real-time basis via social media platforms alongside studies with a top-down perspective. YouTube can provide the historian with multiple perspectives, opening up research to the possibility of a more sourceinclusive approach (albeit carefully considered) towards doing multidisciplinary or interdisciplinary studies. In this article the worthiness of YouTube as a form of historical source material was investigated and considered. To do so a case study was used of the 2015-2017 drought in the Vaal Triangle. Ordinary people on the social media platform YouTube shared their experiences and observations on the drought. It was found that YouTube's value as a source for historical inquiry on the impact of long-term disasters such as drought on people in the 21st century can serve to supplement the use of more traditional physical records, such as newspapers and official records, even though elements of temporality and possible fiction may feature.

97. C. Jewitt, "An Introduction to Using Video for Research", unpublished NCRM Working Paper, at https://goo.gl/4748BS p 3, accessed 19 August 2017.

98. This is also visible in big-data mining research where the study is primarily of a quantitative nature.

99. Oushakine, "Remembering in Public", p 279. 
YouTube, similar to several other types of sources, is a form of expression used in present circumstances, and while the data is available historians should embrace the opportunity to study past events from this source. Some critics may argue that the changing nature of technology hinders the longevity of these videos and that therefore the practical incorporation of YouTube into historical research is questionable. As an emotionally-affecting, yet momentary source of data it carries great value which could, if left unstudied and unpreserved, be lost in the maelstrom of shared memories over the years to come. It may well be that although YouTube provides historians an entirely new perspective on historical events (audio and visual), its different attributes (e.g. its possible lack of longevity and/or ability to capture memories and perspectives shared in real-time) still call for in-depth internal and external source criticism (inclusive of language and style) which should already be part of the historian's methodology.

\section{REFERENCES}

Aisha, T.S., Wok, S., Manaf, A.M.A. and Ismail, R., "Exploring the Use of Social Media During the 2014 Flood in Malaysia", Procedia: Social and Behavioral Sciences, 211 (25 November 2015).

Allen, B. and Montell, W.L., From Memory to History: Using Oral Historical Sources in Local Historical Research (American Association for State and Local History, Nashville, 1982).

Anon., "Boere in Nood", at https://www.youtube.com/watch?v=0oXBVCjWryw Accessed 28 June 2017.

Bahta, Y.T., Jordaan, A. and Muyambo, F., “Communal Farmers' Perception of Drought in South Africa: Policy Implication for Drought Risk Reduction”, International Journal of Disaster Risk Reduction, 20 (18 October 2016).

Bartie, A. and McIvor, A., "Oral History in Scotland", Scottish Historical Review, 92, 234 (2013).

Beninger, K., Fry, A., Jago, N., Lepps, H., Nass, L. and Silvester, H., "Research Using Social Media: Users' Views", NatCen Social Research, (2014).

Bloomberg [?], "Farms Face Water Cuts", The Citizen, 3 November 2015.

Cilliers, S., "Droogte: Boere in NW Kry Hulp", Beeld, 23 December 2013.

Classen, C., Kinnebrock, S. and Löblich, M., "Towards Web History: Sources, Methods, and Challenges in the Digital Age - An Introduction", Historical Social Research / Historische Sozialforschung, 37, 4, 142(2012).

Connell D., Bunbury, B., Willis R. and Linn R. (interviewers), "Drought Oral History Project", National Library of Australia, Canberra, at https://goo.gl/7qi4PI Accessed 1 October 2017.

Dadabhay, A., "The Vaal Dam - 29\% Water Level, Save Water, Drone Footage", at https://www.youtube.com/watch?v=NKLpYTz4Lac Accessed 22 June 2017.

Derry, S.J., Pea, R.D., Barron, B., Engle, R.A., Erickson, F., Goldman, R., Hall, R., Koschmann, T., Lemke, J.L. and Sherin, M.G., "Conducting Video Research in the Learning Sciences: Guidance on Selection, Analysis, Technology, and Ethics", The Journal of the Learning Sciences, 19, 1(2010). 
Dickey, M.R., "The 22 Key Turning Points in the History of YouTube", Business Insider, businessinsider.com (2013), at https://goo.gl/nZGjDV Accessed 26 May 2017.

Diggs, D.M., "Drought Experience and Perception of Climatic Change among Great Plains Farmers", Great Plains Research, 1, 1 (1991).

Du Bruyn, D., "Oral Testimonies as a Source of Community History, with Special Reference to the Batho Project, Bloemfontein", South African Journal of Cultural History, 24, 2(2010).

Elum, Z.A., Modise, D.M. and Marr, A., "Farmers' Perception of Climate Change and Responsive Strategies in Three Selected Provinces of South Africa", Climate Risk Management, 16(2017).

Grobler, D., "The Vaal Dam - 2016 Drought", available online at https://www.youtube.com/watch?v=UCA8X0HRxgM Accessed 28 June 2017.

Grobler, D. "Vaal Dam 4 (at 100\%) in 4K", available online at https://www.youtube.com/watch?v=smWeC62rauo Accessed 28 June 2017.

Griessel, C., "Water Crisis Vaal Dam - 11 October 2016" available online at https://www.youtube.com/watch?v=5FVmTXDGGc8 Accessed 22 June 2017.

Gouws, C., "Vestiging langs die Vaalrivier in die Omgewing van die Vredefortkoepel, 1840-2012", PhD thesis North-West University, Vaal Campus, 2013.

Gunn, S. and Faire, L., Research Methods for History (Edinburgh University Press, Edinburgh, 2012), at https://goo.gl/jK2WCK Accessed 9 August 2017.

Heathcote, R.L., "Drought in Australia: A Problem of Perception”, Geographical Review, 59, 2 (1969).

Heathcote, R.L., "Drought in Australia: Still a Problem of Perception?", GeoJournal, 16, 4 (1988).

Hinton, S. and Hjorth, L., Understanding Social Media (Sage, London, 2013).

Hunter, B., Gray, M. and Edwards, B., "The Use of Social Surveys to Measure Drought and the Impact of Drought", Social Indicators Research, 113, 1(2013).

Jewitt, C., "An Introduction to Using Video for Research", Unpublished NCRM Working Paper, 2012, at https://goo.gl/4748BS Accessed 19 August 2017.

Jimta, S., "Water Levels Critical!", Daily Sun, 3 November 2016.

Kaplan, A.M. and Haenlein, M., "Users of the World, Unite! The Challenges and Opportunities of Social Media", Business Horizons, 53, 1(2010).

Kings, S., "Full Horror of Drought Emerges", Mail \& Guardian, 29 January 2016.

Kite, S., Lemons S. and Paustenbaugh S., "Dust, Drought and Dreams Gone Dry: Oklahoma Women and the Dust Bowl Oral History Project", Oklahoma State University Library, c. 2002, at https://goo.gl/6SdPFs Accessed 1 October 2017.

Knoblauch, H., Schnettler, B., Raab, J. and Soeffner, H.-G., Video Analysis: Methodology and Methods, Qualitative Audiovisual Data Analysis in Sociology (Peter Lang, Frankfurt am Main, 2012), at https://goo.gl/x6XS6e Accessed 1 November 2017.

Kousha, K., Thelwall, M. and Abdoli, M., "The Role of Online Videos in Research Communication: A Content Analysis of YouTube Videos Cited in Academic Publications", Journal of the Association for Information Science and Technology, 63, 9(2012).

Krippendorff, K., Content Analysis: An Introduction to its Methodology (Sage, Los Angeles, 2013). 
Laurier, E., "YouTube: Using Third Party Video as Research Data", Unpublished paper, University of Edinburgh, School of GeoSciences, at https://goo.gl/ENLnqZ Accessed 11 October 2017.

Leavy, P., Oral History: Understanding Qualitative Research (Oxford University Press, Oxford, 2011), at https://goo.gl/hZQNYL Accessed 18 November 2017.

Lester, S., "An Introduction to Phenomenological Research", Stan Lester Developments, Taunton, 1999, at https://goo.gl/rQLcij Accessed 9 April 2017.

Levinson, P. New New Media, 2nd ed. (Pearson, Boston, 2013).

Lindsay, B.R., "Social Media and Disasters: Current Uses, Future Options, and Policy Considerations", 2011, Congressional Research Service Washington DC, R41987.

Mandleni, B. and Anim, F.D.K., "Perceptions of Cattle and Sheep Farmers on Climate Change and Adaptation in the Eastern Cape Province of South Africa", Journal of Human Ecology, 34, 2(2011).

Marwick, A., The Nature of History, 3rd ed. (MacMillan, Hampshire, 1989).

Marwick, A., The New Nature of History: Knowledge, Evidence, Language (Palgrave, Basingstoke, 2001).

McEndoo, J., "The State of Social Media in South Africa 2015", BlueMagnet, at https://goo.gl/o9i28L Accessed 22 April 2017.

McKee, A., "YouTube versus the National Film and Sound Archive: Which is the More Useful Resource for Historians of Australian Television?", Television \& New Media, 12, 2(2011).

Mendoza, M., Poblete, B. and Castillo, C. "Twitter under Crisis: Can We Trust What We RT?", Paper presented at the first workshop on social media analytics (SOMA '10), Washington DC, 25 July 2010.

Nyoni, P. and Velempini, M., "Data Protection Laws and Privacy on Facebook", South African Journal of Information Management, 17, 1 (2015).

Oggolder, C., "Inside - Outside: Web History and the Ambivalent Relationship between Old and New Media", Historical Social Research/ Historische Sozialforschung, 37, 4, 142(2012), pp 134-149.

Oushakine, S.A., "Remembering in Public: On the Affective Management of History", Ab Imperio, 1(2013).

Riukulehto, S. (ed.), Between Time and Space (Cambridge Scholars' Publishing, Newcastle upon Tyne, 2015).

SABC Digital News, "Water Released in Sterkfontein Dam to Boost Levels at the Vaal Dam", https://www.youtube.com/watch?v=ZttqF9KXNtI Accessed 22 June 2017.

Salzmann, N., Huggel, C., Nussbaumer, S.U. and Ziervogel, G. (eds), Climate Change Adaptation Strategies, An Upstream-downstream Perspective (Springer, New York, 2016).

Schellnack-Kelly, I. and Jiyane, V., "Tackling Environmental Issues in the Digital Age through Oral Histories and Oral Traditions from the iSimangaliso Wetland", Historia, 2(2017).

Schnettler, B. and Raab, J., "Interpretative Visual Analysis Developments: State of the Art and Pending Problems", Historical Social Research/ Historische Sozialforschung, 34, 2, 128(2009). 
Schwarzenegger, C., "Exploring Digital Yesterdays: Reflections on New Media and the Future of Communication History", Historical Social Research/ Historische Sozialforschung, 37, 4, 142 (2012).

Sedrez, L.F., "The Use of the Internet as a Source for Environmental History", Electronic Green Journal, 1, 8, at https://goo.gl/8KRPgU Accessed 31 October 2017.

Sedrez, L., "Of Water, Narratives, and the Uses of Environmental History", The Rachel Carson Center, at https://goo.gl/ZYwCdg Accessed 27 October 2017.

Shimpi, V.J. and Ade, R.R., "Understanding the 2016 Drought in India by Social Media Data Mining", Communications on Applied Electronics (CAE), 5, 6(2016).

Sinoga, J.D.R. and Gross, T.L., "Droughts and their Social Perception in the Mass Media (Southern Spain)", International Journal of Climatology, 33, 3(2013).

Stander, O.P.J., "Die Voorkoms van Wit Armoede in Oudtshoorn tussen 1914-1937", $\mathrm{PhD}$ thesis, University of Stellenbosch, 2017.

StatsSA, "Statistics by Place", at https://goo.gl/JbgGE4, (2011), Accessed 5 February 2018.

Tang, Z., Zhang, L., Xu, F. and Vo, H., "Examining the Role of Social Media in California's Drought Risk Management in 2014", Natural Hazards, 79, 1(2015).

Tempelhoff, J.W.N., Townspeople of the Soutpansberg: A Centenary of Louis Trichardt (1899-1999) (Greater Louis Trichardt TLC, 1999).

Tosh, J., The Pursuit of History: Aims, Methods, and New Directions in the Study of Modern History, 3rd ed. (Longman, Harlow, 2000).

Townsend, L. and Wallace, C., "Social Media Research: A Guide to Ethics”, Unpublished paper, University of Aberdeen, Economic and Social Research Council, 2016.

Uimonen, P., "Internet and Social Media: Anthropological Aspects", in J.D. Wright (ed.), International Encyclopedia of the Social \& Behavioral Sciences, 2nd ed. (Elsevier, Amsterdam, 2015).

Van Eeden, E.S., "Challenging Traditional Ways of Thinking and Doing Local/ Regional History Research in South Africa: Some Global Learning and Sharing", International Journal of Regional and Local History, 9, 1 (May 2014).

Van Eeden, E.S., "Regional, Local, Urban and Rural History as Nearby Spaces and Places: Historiographical and Methodological Reflections", New Contree, Special Edition, 63(2012).

Van Vuuren, L., In the Footsteps of Giants: Exploring the History of South Africa's Large Dams (Water Research Commission, Gezina, 2012).

Vogel C. and Van Zyl, K., "Drought: In Search of Sustainable Solutions to a Persistent, 'Wicked' Problem in South Africa”, in Salzmann N., Huggel C., Nussbaumer S.U. and Ziervogel G. (eds), Climate Change Adaptation Strategies, An Upstreamdownstream Perspective (Springer, New York, 2016).

Wachowich, N. and Scobie, W., "Uploading Selves: Inuit Digital Storytelling on YouTube", Études/Inuit Studies, 34, 2(2010).

Woudenberg, D.L., Wilhite, D.A. and Hayes, M.J., "Perception of Drought Hazard and its Sociological Impacts in South-Central Nebraska", Great Plains Research, 18, 1 (2008).

Wright, J.D. (ed.), International Encyclopedia of the Social and Behavioral Sciences (Elsevier, Amsterdam, 2015). 
Yates, D. and Paquette, S., "Emergency Knowledge Management and Social Media Technologies: A Case Study of the 2010 Haitian Earthquake", International Journal of Information Management, 31, 1(2011). 